\title{
Payment for Environmental Services in Nepal \\ (A Case Study of Shivapuri National Park, Kathmandu, Nepal)
}

\section{Kamal J ung Kunwar ${ }^{1}$}

\begin{abstract}
With a view to highlight the issues of Payment for Environmental Services (PES) in Nepal, the paper aims at providing information on possible environmental goods and services rendered by the Shivapuri National Park (ShNP), Kathmandu. It also endeavors to explore the policy issues with regards to PES in Nepal. Secondary information was obtained through published and unpublished literatures and office records of ShNP whereas primary information was generated through various Rapid Appraisal tools; such as informal discussion with park officials, semi-structured interview, field observation etc.

Despite the ShNP's role in providing environmental goods and services to the dwellers of Kathmandu metropolitan, the local inhabitants have not been benefited from such services. There has been low level of awareness on the issues such as environmental goods and services and possible benefits to be obtained and its equitable sharing. It is the dire need that policy should focus on these issues so that all the stakeholders could be benefited from the conservation and management of protected areas and forests in the country.
\end{abstract}

Key Words: Payment for environmental services, Shivapuri national park, Upstream and downstream relationship, Benefit sharing, Free riders.

\section{Introduction}

Environmental services are hydrological services, carbon sequestration, biodiversity services, recreational services, landscape or scenic beauty. Environmental valuation is largely based on the assumption that individuals are willing to pay for environmental gains and conversely, are willing to accept compensation for some environmental losses.

Payment for Environmental Services (PES) is a mechanism to improve the provision of indirect environmental services in which providers of environmental services receive direct payments from the users of these services. PES mechanisms are usually implemented for hydrological services as upstream land uses affect quantity, quality, and timing of water flows downstream. Service providers and service users (downstream beneficiaries) negotiate on desired land use practices upstream and the amount of payment to compensate for making such changes.

Wunder (2005) has identified four types of PES that currently stand out: (i) carbon sequestration and storage (electricity companies are paying farmers for planting and maintaining additional trees), (ii) biodiversity protection (conservation donors are paying local people for setting aside

\footnotetext{
$\bar{l}$ Assistant environment officer, Ministry of Forest \& Soil Conservation, Kathmandu, Nepal, kalpa2062@gmail.com
} 
or naturally restoring areas to create a biological corridor), (iii) watershed protection (downstream water users are paying upstream farmers for adopting land uses that limit deforestation, erosion, and flooding risks, and (iv) landscape beauty ( a tourism operator is paying a local community not to hunt in a forest being used for tourists' wildlife viewing).

According to CIFOR (2002), regeneration of dry secondary forests in central India, could double carbon sequestration from 27.3 to $55.2 \mathrm{t} / \mathrm{ha}$ in ten years at very modest cost. Similarly, it has also estimated that suitably targeted forest project can produce carbon offset at the predicated market price of US\$ 15-20/ton. In this regard, community forests in Nepal can be taken as potential carbon sinks to generate substantial income to our Community Forest User Groups (CFUGs) by selling carbon credit at international markets. (Mararjan, 2004)

Water supplies yield significant financial and economic benefits for downstream users, however, those benefits need to be identified and valued properly to convince the decision-makers about importance of managing upper catchments as a part of water supply infrastructure. Assessment was done to value the water in different uses (hydropower, irrigated agriculture, urban consumption) and for different users, enabling the financial and economic impacts of land use change on water service delivery to be calculated (Karna, 2008).

Shivapuri National Park (ShNP) contributes water to over 4,000 ha of agricultural farms. Water from the Sundarijal sub-catchment is collected into a reservoir and channeled to a hydropower plant located in Sundarijal that generates about 4,231,000 Kilowatt-hour of electricity a year. This water is processed and transferred to the city for the distribution to domestic consumers who use about 33.3 million cubic meters of water a year from this source. Each of this water uses generating huge financial revenues and economic benefits. Currently, the net financial value-added across different water uses totals NPR 306 million or some US\$ 7.65 million a year (Karna, 2008).

Some of the very recent studies are more focused to economic valuation of natural resources and generating information on feasibility to set up PES mechanism in Nepal. A very recent one on economic valuation has highlighted the importance of Churia hills resources for local communities and the importance of Churia watersheds for hydrological benefits to downstream people, and generated much needed background information for setting up PES schemes.

On the implementation front, a PES like scheme being implemented in Kulekhani hydropower in Makawanpur District is a very good and pioneering initiative. Kulekhani watershed supplies water to two hydroelectric plants that generate a total of $92 \mathrm{MW}$ of electricity, and Nepal Electricity Authority earns revenue from its sale. However, its operation often suffered for limited availability of water and heavy sedimentation in water reservoir. To address these issues, Winrock Nepal facilitated the setup and operation of a reward mechanism to upland communities to motivate them to change their land use patterns. A certain percentage of hydropower royalty is allocated for the development activities for the upland communities in this watershed. Land use changes in upland area has visibly resulted in reduced sedimentation and increased dry season water flow to the reservoir, which in economic terms are estimated at NPR 3.12 million a year.

Buffer zone programme and conservation area management are others examples of Payment of environment services of biodiversity conservation and management. Aesthetic and scenic 
beauty helps to develop eco-tourism in these areas and earning from the tourism development sharing with local communities for the sake of socio-economic development and livelihoods support.

Basic and required policies and institutional arrangement for PES schemes are also already in place. The National Parks and Wildlife Conservation Act 1973, the Local Self Governance Act 1999, the Electricity Act 1992, the Forest Act 1993, among few others, contain the concept of benefit sharing (Karna, 2008). In the buffer zone management programs 50\% revenue generated by respective park and reserve directly goes to local communities for their socioeconomic development and biodiversity conservation in Buffer zone.

PES being a new concept and it is a burning issue for Nepal, many stakeholders, service providers and beneficiaries are not aware of it. Capacity building of concerned organizations and policy makers is inevitable. Moreover, awareness creation among local communities is also important.

\section{Methodology}

\section{Study site}

Shivapuri National Park (ShNP) is located between $27^{\circ} 45^{\prime}$ and $27^{\circ} 52^{\prime}$ north latitude and $85^{\circ} 15^{\prime}$ and $85^{\circ}$ $30^{\prime}$ East longitudes. Covering an area of about 144 sqkm of Kathmandu, Nuwakot, and Sindhupalchowk Districts of Central Development Region, the park stretches about 20-24 $\mathrm{km}$ from east to west and about $8-10 \mathrm{~km}$ from

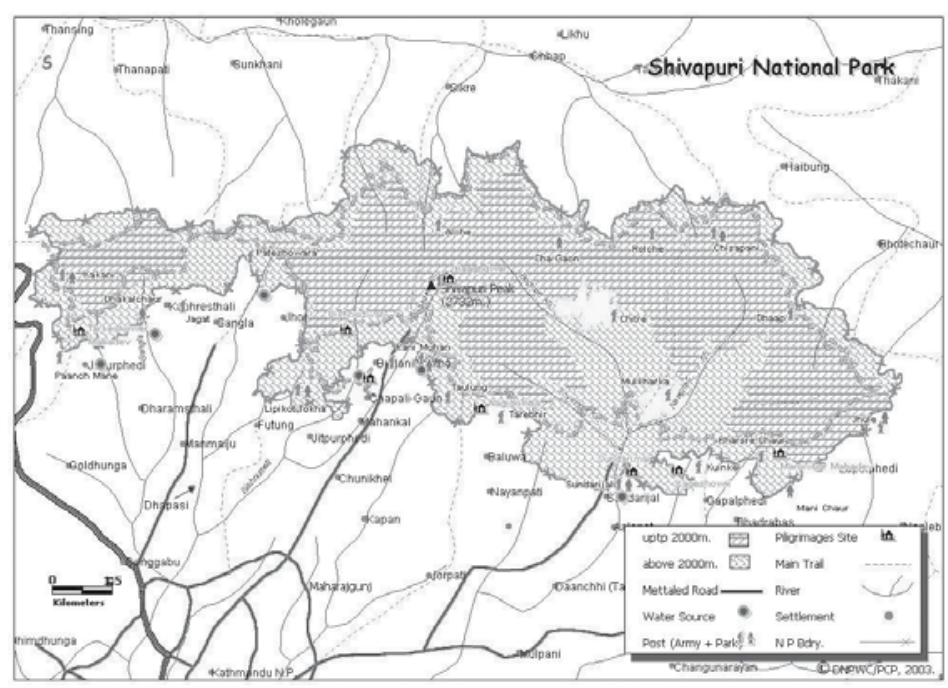
north to south.

ShNP is located about $12 \mathrm{~km}$ north of Kathmandu. Lying in the middle mountain physiographic zone, its elevation ranges from 1320 meters above sea level to 2732 masl. The park is rich in biodiversity with more than 2,000 plant species, 21 mammals and 180 birds, and has also cultural and livelihoods values for local communities.

\section{Data collection and analysis}

Technical and policy documents were extensively reviewed to derive existing information. Secondary information was obtained through published and unpublished literatures and office records of ShNP whereas primary information was generated through various Rapid Appraisal tools; such as informal discussion with park officials, semi-structured interview, field observation etc. 
Collected information was compiled and organized systematically. The data were analyzed using MS-Excel with frequency and bar diagrams. The descriptive research design was adopted.

\section{Result and Discussions}

\section{Socio-economic condition of local communities}

\section{- Population}

According to 2001 census there are 101,493 people living of ShNP and its buffer zone. About 350 households (Okhareni and Mulkharka villages) are inside the park. This population exhibits an average household size of 5.5 persons. The dominant ethnic group adjacent to the park is Tamang, a group that has always been marginalized socially and economically.

\section{- Landholding capacity and occupation}

Ownership of land is a powerful cultural and economic significance governing food sufficiency and livelihoods of the households. The land holding is an average of 0.2 hectares (KhatriChhetri, 1993) in Shivapuri area. Some of the households are either landless or have no land title.

Agriculture and livestock are still the dominant livelihood patterns for the people of Shivapuri area as more than $90 \%$ of the households are engaged directly or indirectly in these occupations. Agriculture in the area is characterized by mixed farming enterprise where people cultivate crops, raise livestock, grow vegetables and transplant fruit trees. However, around half of the populations are suffering from food deficiency for 4-10 months each year.

\section{- Crop damage and livestock depredation}

Invasion of wildlife in the surrounding area has tremendously increased after the designating Shivapuri as a protected area resulting high crop damage and livestock depredation. The most destructive wild animal in terms crop damage appears to be wild boar. However, birds, monkeys and porcupine are also reported as serious pests to crop.

In addition to crop raiding, some isolated cases of livestock depredation by wild animal are also reported. Common leopard, wildcat and jackal are reported to be the major predators. Due to excessive pressure on their habitat, there may be some possibilities that the wild animals may harm to human beings as well.

\section{Environmental goods and services of ShNP}

\section{- Water recharge and discharge}

Rivers, ponds, marshlands and reservoirs are the major wetlands in this park. Preliminary survey shows that about $0.24 \mathrm{sqkm}(0.17 \%)$ is covered by all the wetlands in ShNP. The major wetlands contributing recharge of the fresh water to Bagmati, Sunkoshi and Trishuli rivers. 
ShNP area is important for drinking water, irrigation, traditional grindling mills as well as it has wider scope of ecological value. Detailed studies have yet to be made for northern aspect. However, southern aspect has 226.7 million litres water discharge per day. It is the worth of water resources but demand on drinking water for Kathmandu is 140 million litre per day. And presently collection and supply is only 29.5 million litre per day. Drinking Water Corporation charged as per litre to the consumer and earning huge amount of money annually.

\section{- Tourism, recreation and aesthetic value}

Scenic beauty, historical and religious sites, outdoor adventure like nature-walk, hiking, trekking and mountain biking, and wildlife-tourism (Bird watching) are some of the potential attractions of ShNP. Currently, tourism is developed in surrounding of the important religious sites like Budhanilkantha, Nagi-Gumba, Sundarijal, Bajrayogini and the scenic-spots like Kakani and Chisapani.

The park is linked by three major road-networks from the valley: Sundarijal, Budhanilkantha, Tokha and Kakani. Inside the park, there is $95 \mathrm{~km}$ graveled road, $83 \mathrm{~km}$ foot trails constructed for trekking and village walks route, bird watching, and educational tours to the students

\section{a) No. of tourists}

The visitor's records of ShNP shows that the park has been visited by an average of 49,200 visitors annually during last five years, but in the last year more than 70,000 tourists visited in the park. Out of this numbers Nepali visitors are ten folds higher than the foreigner.

\section{b) Revenue collection and tourism enterprise}

The park revenue is accounted only to entry fee more than $95 \%$ and others sources of revenue collection are penalties, tender form, forest products and miscellaneous. Bar diagram shows that average revenue is NRs. 2.9 millions.

Local people's involvement in tourism activities is negligible compared to a

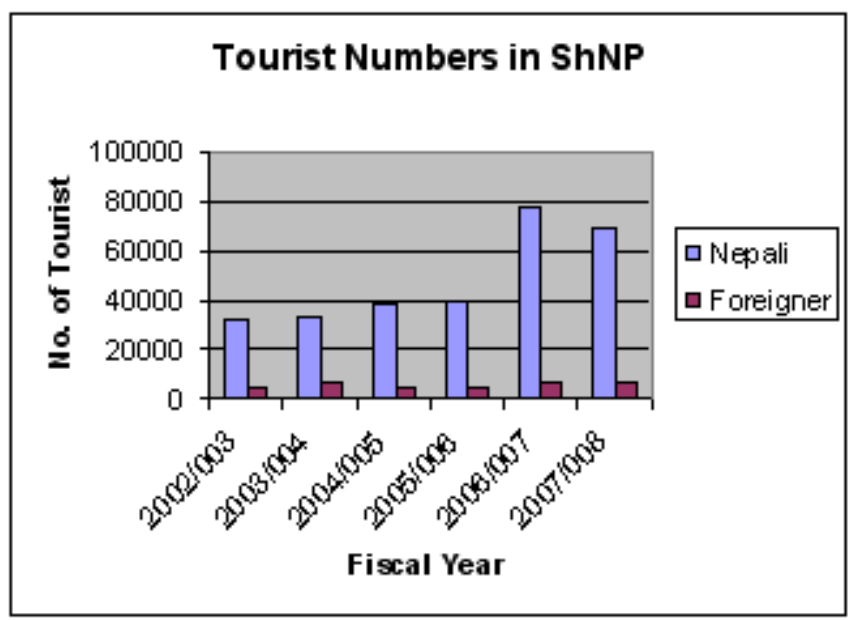

Source: ShNP, Office record, 2008

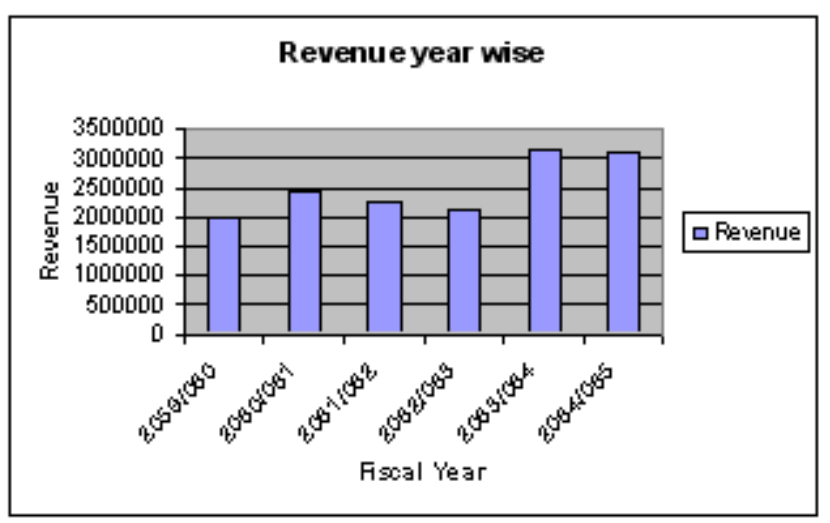

Source: ShNP, Office record, 2008 
large number of tourists visiting the park. About 11 households hold local lodges, 10 households hold local restaurants, and 32 households hold teashops. Altogether 150 people were engaged in these food-based activities.

\section{- Biodiversity}

The park harbors 2122 flowering plants ( $41 \%$ out of 5067 identified in Nepal) with 16 endemic (Shakya et.al, 1997). More than 35 species of Non-Timber Forest Products (NTFPs) including 129 species of mushrooms are found in the park. The park comprises mainly four forest types namely lower mixed hardwood forest, Chirpine forests, upper mixed hardwood forests, Oak forests (Annon, 1992).

ShNP supports a large number of wildlife species. There are 21 species of mammals out of nine are threatened species. It harbors 177 species of birds and 14 of them are threatened including spring babbler, which is an endemic species. There are more than 102 species of butterflies.

\section{- Land use pattern}

The land use pattern in and around ShNP is predominated by forest (40.7\%), followed by agriculture $(35.3 \%)$, grassland with shrubs $(2.6 \%)$, landslides $(0.5 \%)$, settlements, $(0.9 \%)$, riverine features $(0.2 \%)$, and abandoned land $(2.0 \%)$.

\section{- Religious and cultural value}

Shivapuri hill is the most important sanctity and famous from time immemorial. Religiously, it is respected from both Hinduism and Buddhism. For Hindus, it is an abode of Lord Shiva, and for Buddhist, it is sanctity for its cultural and religious heritage. It is a Shaktipith- source of spiritual power, for both religions. For a long time to date this sacred forest has given shelter to countless learned saints who ultimately found their way to salvation while meditating in this place of tranquility.

Religiously the water of the Bagmati River is used for holy bath in Bagdwar. The holy water of Vishnumati in Vishnupaduka is culturally important to take holy bath on the occasion of New Year of Bikram Sambat.

\section{- Carbon sequestration}

Kathmandu city is undergoing catastrophic environmental degradation primarily from air pollution, which has caused significant number of respiratory related illnesses in the valley's resident population. The air pollution caused from burning of fossil fuel leaves a thick cloud of pollutants, mainly $\mathrm{CO}_{2}$ suspended in the air for a long period until wind or rain disperses it.

In this scenario, ShNP plays a vital role as sink by sequestering carbon from the source and reducing the time taken to clean the valley's environment. The valley's entire population shares sequestering $\mathrm{CO}_{2}$ by ShNP as an ancillary benefits. 


\section{- Watershed management}

Topography is mostly mountainous with steep slopes of $>30 \%$ at least in $50 \%$ of the total area of the park. Because of the steep topography and the nature of soil, soil erosion is very high in places particularly in the northern part of the park. Land slide, gullies, sheet erosion in the sloping terraces, and stream bank erosion are common all over Shivapuri. Major causes of such hazards include (a) construction of road on steep southern and northern slopes (b) overgrazing, and (c) abandoned agriculture land, which is prone to overgrazing and lacks maintenance of terraces.

Shivapuri is the origin of some important river systems including Bagmati, and Vishumati, which are the major watersheds. There are some sub-watersheds of small streams including Rudramati, Yagmati and Dhobi Kholas. Although, Trishuli, Sunkoshi, Bhotekoshi, Indrawati, Melamchi and Balephi are not within the influence zone of ShNP.

Several catchments covering $42 \mathrm{sqkm}$ within Shivapuri are the main sources of surface and ground drinking water for the Kathmandu valley. The largest one is Sundarijal catchment (32.7\%), which drains into Bagmati. In total, Shivapuri provides almost $40 \%$ of the surface drinking water, which comes from various sites. The total amount of drinking water tapped from various sites of Shivapuri is 100-140 million liters/day.

By proper management of watershed flood, landslide and soil erosion is controlled which helps to reduce property loss and human casualties. Likewise, land productivity is increased through irrigation and decomposition and deposition of leaf litter. Sedimentation is decreased and if valuated loss of property, it contributes millions of money not only the local communities but also the downstream communities.

The Drinking Water Department has neither taken any initiative to protect the water source area nor provided incentives to communities involved in watershed protection. It is essential to make a necessary arrangement to plough back certain percent of the drinking water revenue for conservation efforts and livelihood support activities in the area. The up-stream area should be strictly protected for a continuous flow of drinking water to the Kathmandu city.

\section{- Community forests and resource dependency}

Access to common property resources, particularly forests is vital to the livelihood of the rural communities throughout the country. And people's reliance on ShNP forest is not exceptional. Lack of alternatives, people's dependency on park forests especially for firewood, fodder, timber and grazing space is still continued.

As the economy is predominately agro-based, dependency on forest has become imperative. One of the reasons of high dependency on park forest is that forest resources outside the park is poorly developed and alternative sources of energy are either not available or are costly for the poor people. Hence, people are forced to enter the park and compelled to use forest resources. Total population affected by or dependent on the park is 95,837 from 18,235 households in and around ShNP. Dependent population per sq km of the park is 666 persons (NARM, 2004). 
About 20 Community Forests (CFs) in Kathmandu and 10 CFs in Nuwakot have been handed over to communities by respective DFOs but they are not adequate to meet the demand of local communities.

\section{Identification of manager's contribution and benefits}

\section{- Imposed to use resources to the local communities}

According to the office record of ShNP in the last fiscal year, more than 110 people were punished due to illegal activities inside the park. It shows that there is pressure on the forest resources from the surrounding communities. They are highly dependent upon the park resources for their subsistence daily life and livelihoods.

Although there is $110 \mathrm{~km}$ loose stonewall to separate village with national park but it does not function, crop damage, and livestock depredation are the common and serious problems. It is creating conflict between park and local communities.

People are suffering from various aspects of the park management however, people are contributing to conserve and manage the ShNP and park resources.

On average, crop damage costs are worth some NPR 2,873 a year for each park-dwelling household. Loss of use of park resources due to restrictions on harvesting amounts to some NPR 16,000 a year (comprising timber and NTFP use), and loss of access to agricultural markets incurs average opportunity costs of NPR 8,000 per household per year.

\section{- Management and conservation of resources and management cost}

It was established as watershed area in 1976 and gazeeted as National Park in 2002. Ultimate goal of this park is to conserve and manage the watershed area of Sundarijal which is the main source of drinking water supply in Kathmandu valley. Total Nepalese Army staffs are 849 for the protection purpose and annual budget including Rashan is NRs. 51.8 Millions (U\$ 740,159) and National Park has 60 staffs for the protection and management of park and park resources. Annual budget is NRs. 11.0 Millions (U\$157142). Altogether, there are 909 staffs and budget is NRs. 62.8 million. All of these amounts of money directly go from the national treasure

\section{- Benefits to the resource managers}

Local communities are getting forest products from the park either legally or illegally. Water is used for irrigation, drinking water, griddling machine, livestock pond and others households uses.

People are getting benefits from the tourism enterprises. Altogether there are 25 hotels, restaurants, lodges, teashops and other facilities and services in and around park. Some people are getting employment opportunities from the tourism. Natural beauties and environmental services are others benefits getting by local communities.

It reduced landslide and soil erosion of the catchment area and automatically it decreased property loss and human casualties of local settlements. Another important benefit is it increased land productivity of local farmers. 


\section{Distribution}

Benefit sharing mechanisms is not in the place. Institution set up is essential in the local level either through local governance bodies or declaration of Buffer zone as soon as possible. To participate local communities in decision making, planning process, implementation, monitoring and evaluation is the most important.

Community forests are the vital to fulfill the basic needs of forest products of local communities. It would also be the source of income generation and employment opportunities to support their livelihoods.

\section{Conclusion}

PES is a new concept and burning issue in the recent days. It is pro-poor and equitable benefit sharing mechanism. Moreover, PES enhances livelihoods, sustainable development, and improvement of socio-economic condition.

There is lack of clear provision in policy, acts, rules, regulations, and guidelines to address the issue of PES and benefit sharing. Appropriate environmental governance policy formulation and institutional set up is required.

Managers are suffering and free riders are getting benefits so, appropriate benefit sharing mechanism should be developed to resolve the problem of upstream and downstream conflict.

Awareness creation and empowerment of local communities is most essential to improve their livelihoods and biodiversity conservation through PES mechanism.

Declaration of Buffer Zone (BZ) is the first step to take initiation for PES. After declaration of BZ, at least $50 \%$ amount of revenue directly goes to buffer zone communities. That money will be used to improve their socio-economic condition of local communities and biodiversity conservation of $\mathrm{BZ}$.

Without any economic benefits local communities are suffering by livestock damage, crop depredation by wild animals, imposed use of natural resources. Moreover, restriction on land use options and huge amount of money has been invested government for the conservation and management of ShNP. To compensate such contributions and sacrifices PES mechanism is inevitable and the best.

Environmental benefits is also needed to be identified and valued properly to convince the decision makers about importance of managing upper catchments as a part of water supply infrastructure.

\section{Acknowledgement}

Mr. Puran Bhakta Shrestha, Chief Conservation Officer of ShNP provided access to recent information and resources available in the park. Assistant Conservation Officer, Mr. Hari Bhadra Acharya, Ranger Mr. Bishnu Prasad Pandey, Mr. Sarojmani Paudel, Office Assistant, Mr. Keshav Parajuli, Mr. Basu Dev Chalise and other staffs of ShNP not only provided information but also assisted in the field visit. I would like to extend gratitude to all of them. 


\section{References:}

BPP 1995a. Biodiversity Profile of the Midhills of Nepal. BPP Publication no. 13. DNPWC, Kathmandu.

CIFOR (2002) Making Forest Carbon Markets Work for Low-income Producers, CIFOR Info-brief, Oct. 2003, No. 2. Indonesia.

Department of Forest Research and Survey, 2008. Payment for Environmental Services: an emerging issue to be addressed. Banko Janakari 18(1):1

Department of National Parks and Wildlife Conservation, 2006. Shivapuri National Park

FAO/HMG, 1996. Shivapuri Management Plan: Technical recommendations and policy design for the protection and development fo the Shivapuri area including the participatory management of Shivapuri Resources. Kathmandu: (GCP/NEP/048/NOR).

Karn, Prakash K. 2008. Making Payment for environmental services (PES) work: A case study of Shivapuri National Park, Nepal. In Shifting Paradigms in Protected Area Management (Ed) Bajracharya S. B., Dahal, N., NTNC, Nepal,171-185.

Khatri Chheri, J. B. 1993. A Study on Socio-economic in Shivapuri Watershed Area. SIWDP, GCP/NEP/048/NOR, Field Document No. 3.

KMTNC, 2004. Shivapuri National Park Management Plan.

Maharjan, Maksha R. 2004. Payment for Environmental Services in Community Forestry. In 25 years of community forestry: Contributing to Millennium Development Goals, proceedings of the fourth National workshop on community forestry (Ed) Kanel, K. et al. Community Forest Division, Department of Forest, Nepal, 371-377.

MOEST, 2008. State of Environment, Brown sector (unpublished).

NARM 2004. Poverty Reduction through Sustainable Management of Protected Areas and Wetlands in Nepal: Processes, modalities, Impacts and Identification of Areas for Future Support, Volumes I and II. JICA, Kathmandu

Shivapuri National Park,2005. Wetlands of Shivapuri National Park.

Wunder, S. (2005). Payment for environmental services: Some nuts and bolts, Occasional paper No. 42. Bogor: Centre for International Forestry Research.

http://www.csc.noaa.gov/text/direct. Environmental valuation: Principles, Techniques, and Applications. NOAA Coastal Services Center 2234 South Hobson Avenue Charleston, SC.

http://go.worldbank.org/51KUO12O50. Payements for Environnemental Services. 